Pediatric

Neurosurgery

Paul Steinbok

Department of Surgery, University of British Columbia, Vancouver, Canada

Pediatr Neurosurg 1998;28:108

Concerning the article by Krieger MD et al.

Pediatr Neurosurg 1997;27:1-11

\title{
Recurrence Patterns and Anaplastic Change in a Long-Term Study of Pilocytic Astrocytomas
}

I read with interest the paper by Krieger et al. [1]. I wish to challenge the recommendation made by the author in their conclusion that 'follow-up MRIs should be obtained at regular intervals even with complete resections, a vigilance necessitated by the development of recurrent disease in 3 of our cases who had total resections'. This recommendation is not in keeping with the results of their study. As the authors state, none of the recurrences were detected on surveillance scans, and it would therefore be more reasonable to conclude that one should wait until the patients became symptomatic before repeating a scan.

\section{Reference}

1 Krieger MD, Gonzalez-Gomez I, Levy ML, McComb JG: Recurrence patterns and anaplastic change in a long-term study of pilocytic astrocytomas. Pediatr Neurosurg 1997;27:1-11.

\section{KARGER}

Fax + 41613061234 E-Mail karger@karger.ch www. karger.com (c) 1998 S. Karger AG, Basel

$1016-2291 / 98 / 0282-0108 \$ 15.00 / 0$

Accessible online at:

http://BioMedNet.com/karger
Prof. Paul Steinbok

British Columbia's Children's Hospital

4480 Oak Street, A325

Vancouver, B.C. V6H 3V4 (Canada)

Tel. +1 604875 2094, Fax +1 604875 3109, E-Mail psteinbok@wpog.childhosp.bc.ca 